\title{
Bringing Laboulbeniales into the 21st century: enhanced techniques for extraction and PCR amplification of DNA from minute ectoparasitic fungi
}

\author{
Danny Haelewaters ${ }^{1,2}$, Michał Gorczak ${ }^{3}$, Walter P. Pfliegler ${ }^{4,5,6}$, András Tartally ${ }^{7}$, Marta Tischer ${ }^{3}$, Marta Wrzosek ${ }^{3}$, Donald H. \\ Pfister $^{1,2}$
}

\begin{abstract}
${ }^{1}$ Department of Organismic and Evolutionary Biology, Harvard University, 22 Divinity Avenue, Cambridge, MA 02138, USA; corresponding author e-mail: dhaelewaters@fas.harvard.edu

${ }^{2}$ Farlow Reference Library and Herbarium of Cryptogamic Botany, Harvard University, 22 Divinity Avenue, Cambridge, MA 02138, USA

${ }^{3}$ Department of Molecular Phylogenetics and Evolution, University of Warsaw, Aleje Ujazdowskie 4, Warsaw, Poland

${ }^{4}$ Department of Genetics and Applied Microbiology, University of Debrecen, Egyetem tér 1, 4032 Debrecen, Hungary

${ }^{5}$ Department of Biotechnology and Microbiology, University of Debrecen, Egyetem tér 1, 4032 Debrecen, Hungary

${ }^{6}$ Postdoctoral Fellowship Programme of the Hungarian Academy of Sciences (MTA), Hungary

${ }^{7}$ Department of Evolutionary Zoology and Human Biology, University of Debrecen, Egyetem tér 1, 4032 Debrecen, Hungary
\end{abstract}

Abstract: Laboulbeniales is one of the most peculiar orders of Ascomycota. These fungi are characterized by an ectoparasitic life-style on arthropods, determinate growth, lack of an asexual stage, high species richness, and intractability to culture. The order Laboulbeniales, sister to Pyxidiophorales, has only recently been assigned a separate class, the Laboulbeniomycetes, based on very few ribosomal DNA sequences. So far, DNA isolations and PCR amplifications have proven difficult. Here, we provide details of isolation techniques and the application of commercially available kits that enable efficient and reliable genetic analyses of these fungi. We provide 43 newly generated Laboulbeniales ribosomal DNA sequences, among which are the first published sequences for species in the genera Gloeandromyces, Herpomyces, Laboulbenia, Monoicomyces, and Polyandromyces. DNA extractions were possible using from 1 to 30 thalli from hosts preserved in ethanol (70-100\%). In two cases, we successfully isolated DNA from thalli on dried insect collections. Laboulbeniales molecular systematics could be substantially enhanced through these improved methods by allowing more complete sampling of both taxa and gene regions.
Key words:

Ascomycota

DNA isolation

insect collections

Laboulbeniales-specific primers ribosomal DNA

unculturable fungi

Article info: Submitted: 14 July 2015; Accepted: 29 October 2015; Published: 4 November 2015.

\section{INTRODUCTION}

Laboulbeniales are obligate ectoparasitic Ascomycota on arthropods. Over 2100 species in 140 genera are described, but many more species await discovery (Weir \& Hammond 1997, Haelewaters \& Yaakop 2014). Laboulbeniales differ from most other non-yeast Ascomycota in that they do not form hyphae but instead form discrete microscopic and multicellular thalli. Their only form of reproduction is sexual, during which they generate sticky ascospores that are usually transmitted directly from infected to uninfected hosts during mating or other contact (De Kesel 1996a). They are moderately to highly host specific; most species are associated with a particular host species (but see, e.g. De Kesel \& Haelewaters 2014). It was experimentally shown that this specificity is driven by several factors: the characteristics of the integument and living conditions of the arthropod host, as well as the nature and availability of nutrients in the habitat chosen by the host (De Kesel 1996b). Study of these fungi also needs some expertise in entomology. Correct identification of a host often facilitates identification of its associated fungi, but since fortuitous infections of hosts occur, it is best to identify these fungi based on their morphology or DNA sequence comparisons. Host-parasite lists are available for some countries (Scheloske 1969, Huldén 1983, Majewski 1994, De Kesel 1998, Santamaría 1998, 2003) and regions (Santamaría et al. 1991). Useful advice about general methodology and identification of Laboulbeniales can be found in Thaxter (1896), Scheloske (1969), Benjamin (1971), Majewski (1994), and Santamaría (1998).

It was only recently that the order Laboulbeniales was recognized as a well-supported lineage in Ascomycota, as the class Laboulbeniomycetes that includes both Laboulbeniales and Pyxidiophorales (Weir \& Blackwell 2001a). This phylogenetic determination was based on four (partial) SSU ribosomal DNA (rDNA) sequences (Pyxidiophora sp.1, Stigmatomyces limnophorae, Hesperomyces coccinelloides, and Zodiomyces vorticellarius). Weir \& Blackwell's (2001a) phylogeny suggested a close relationship with Sordariomycetes. High bootstrap support for this hypothesis

๑) 2015 International Mycological Association

You are free to share - to copy, distribute and transmit the work, under the following conditions:

Attribution: $\quad$ You must attribute the work in the manner specified by the author or licensor (but not in any way that suggests that they endorse you or your use of the work).

Non-commercial: $\quad$ You may not use this work for commercial purposes.

No derivative works: You may not alter, transform, or build upon this work.

For any reuse or distribution, you must make clear to others the license terms of this work, which can be found at http://creativecommons.org/licenses/by-nc-nd/3.0/legalcode. Any of the above conditions can be waived if you get permission from the copyright holder. Nothing in this license impairs or restricts the author's moral rights. 
was later achieved by Schoch et al. (2009) based on a sixgene phylogeny. The order Laboulbeniales was represented in that dataset by only SSU and LSU sequences for two species (Hesperomyces virescens and Stigmatomyces protrudens).

Molecular studies of Laboulbeniales have proven difficult for several reasons. The thalli are microscopic, on average 200-300 $\mu \mathrm{m}$ in length. Among the smallest species known are Rickia euxesti (total length 40-68 $\mu \mathrm{m})$, R. lenoirii (45$67 \mu \mathrm{m}$ ), and Siemaszkoa annae (47-54 $\mu \mathrm{m}$ ) (Thaxter 1896, 1926, Majewski 1994, Santamaría \& Espadaler 2015). At the other end of the size spectrum are Zodiomyces vorticellarius (to $2.75 \mathrm{~mm}$ ) and Laboulbenia kunckelii (2-4 mm) (Giard 1892, Sugiyama \& Phanichapol 1984, Haelewaters unpubl.). For study and extraction of DNA, thalli need to be removed from their host, which requires micro-manipulation techniques and specific tools. Hosts may bear only a few thalli but certain hosts carry multiple, often position-specific species (e.g. Chitonomyces spp., De Kesel \& Haelewaters 2012, Goldmann \& Weir 2012; Hesperomyces coleomegillae and $H$. palustris, Goldmann et al. 2013). Many species are heavily pigmented with melanin in their cell walls, providing rigidity (Weir \& Beakes 1996). This pigment interferes with PCR amplification by binding to the DNA polymerase (Eckhart et al. 2000). Thalli are relatively long-lasting and their form is such that they absorb impacts and friction during their entire existence on the hosts' integument. These tough and resilient cells are difficult to break. Because Laboulbeniales have not been grown in culture to more than a few cells, obtaining DNA from cultured material has been impossible. Only Whisler (1968) was partly successful in this with Stigmatomyces ceratophorus, obtaining 20-celled thalli onto sterile fly wings on brain-heart infusion agar, but perithecia were not produced.

Laboulbeniales are a remarkable clade for their: (1) obligate biotrophy; (2) strictly determinate growth, with development from a two-celled ascospore to a thallus of up to several thousand cells; (3) bilateral symmetry; and (4) loss of germ tubes, hyphae, and conidia. Despite these special features, the order and the class were not included in studies dealing with "major lineages in Ascomycota" (Prieto \& Wedin 2013) or the subphylum Pezizomycotina, to which they belong (Spatafora et al. 2006).

Extraction of DNA using a variety of methods and protocols have given poor results or failed. These include prolonged boiling of thalli (Henson 1992), microwave treatment (Goodwin \& Lee 1993), immersion in liquid nitrogen (Haugland et al. 1999), and direct addition of entire thalli to PCR master mix (Haelewaters 2011). Also, the use of commercial kits (Puregene Kit A, DNeasy Plant Mini Kit, Qiagen; Haelewaters 2011) has so far proven unsuccessful.

The first successful published extraction protocol involved transferring thalli to double distilled (dd) $\mathrm{H}_{2} \mathrm{O}$, air drying, and manually crushing thalli between microscope slides (Weir \& Blackwell 2001a). The success rate for this protocol was $25 \%$. Weir \& Blackwell (2001b) developed an improved technique in which thalli were manually crushed on a microscope slide and picked up with a micropipette facilitated by the use of a bed of dry ice, a modification from previous endeavors based on Conger \& Fairchild (1953) and Lee \& Taylor (1990). The technique from Weir \& Blackwell (2001b) was successful only when hosts were preserved in $95 \%$ ethanol for not more than six months. Thalli taken from dried insect specimens have not been available for molecular phylogenetic analyses because extractions have been unsuccessful with this type of material (Weir \& Blackwell 2001b). This technical difficulty limits both the taxonomical and geographical diversity of species that can be included in phylogenetic studies (e.g. Thaxter 1899, 1900, 1901a, 1901b, 1902, 1905, Weir \& Hammond 1997, Haelewaters et al. 2014, 2015a, 2015b).

Owing to the difficulties in DNA isolation and amplification of phylogenetically informative genes, the molecular phylogenetic relationships within this group have been understudied. Weir \& Hughes (2002) constructed a partial SSU rDNA phylogeny of ten species of Laboulbeniales, representing three subfamilies (Ceratomycetoideae, Laboulbenioideae, Peyritschielloideae). A combined dataset of the partial SSU and ITS rDNA regions was used to study the phenomenon of position specificity in 13 species of Chitonomyces on Laccophilus maculosus (Coleoptera: Dytiscidae; Goldmann \& Weir 2012). Goldmann et al. (2013) described two position specific species of Hesperomyces on Coleomegilla maculata (Coleoptera: Coccinellidae), again based on partial SSU+ITS rDNA. All these studies used the extraction methodology of Weir \& Blackwell (2001b).

We tested more generalized techniques that could be adapted to sample the thalli of Laboulbeniales.

\section{MATERIAL AND METHODS}

\section{Collection}

Insects were collected around the world by ourselves or collaborators using standard entomological methods (sticky traps, light trap, entomological net, and hand collecting) or obtained from the pet store (Blatta lateralis). Insects were killed in $70-100 \%$ ethanol, ethyl acetate vapors, or simply by freezing. Screening for Laboulbeniales was done using a dissecting microscope at $50 x$.

\section{Morphological studies}

Individual thalli were removed from the host using an entomological pin (self-made, sometimes flattened) or the tip of a scalpel. Slide mounts followed techniques for permanent microscope slides (Benjamin 1971, Haelewaters et al. 2015b). Identification of Laboulbeniales followed Thaxter (1908, 1931), Majewski (1994), and De Kesel (2011). Voucher slides are deposited at BP (Botanical Department, Hungarian Natural History Museum), FH (Farlow Herbarium, Harvard University), and WA (Faculty of Biology, University of Warsaw). Herbarium acronyms are according to Thiers 2015.

\section{DNA extraction protocols}

Between one and 30 thalli were removed from each host specimen. In this study we wanted to test the efficacy of different commercial and noncommercial DNA extraction protocols. The following were used: (1) QIAamp DNA Micro 
Kit (Qiagen, Stanford, CA); (2) Extract-N-Amp Plant PCR Kit (Sigma-Aldrich, St Louis, MO); (3) a heat-extraction protocol; and (4) ISOLATE II Plant DNA Kit (Bioline Reagents, London).

(1) QIAamp DNA Micro Kit: DNA was isolated from two to sixteen thalli for each extraction, following the manufacturer's instructions. Some extracts received pre-treatment with liquid nitrogen or two cycles of heating to $95{ }^{\circ} \mathrm{C}$ and freezing on liquid nitrogen.

(2) Modified Extract-N-Amp Plant PCR Kit: The manufacturer's instructions were followed but with $20 \mu \mathrm{L}$ of Extraction Solution (EX) and $60 \mu \mathrm{L}$ of Dilution Solution. One to 20 thalli were removed from the host with the help of a tiny drop of Hoyer's medium ( $30 \mathrm{~g}$ arabic gum, $200 \mathrm{~g}$ chloral

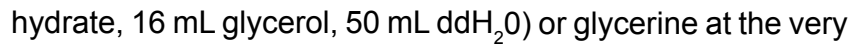
end of a micropin and then added to EX-filled $0.5 \mu \mathrm{L}$ tubes. When hosts were preserved in dried collections, 16-30 thalli were used. Again, the pre-treatment described above was applied for some extracts.

(3) Heat-extraction protocol: This method was adapted from a protocol for single-spore extractions and subsequent PCR reactions (Ferreira \& Glass 1996, based on Goodwin \& Lee 1993). Thalli were removed from the host (3 thalli of Hesperomyces virescens, 20-30 thalli of Rickia wasmannii) or a $\sim 5 \mathrm{~mm}$ portion of a heavily infected Blatta lateralis antenna with Herpomyces stylopygae thalli was removed, placed in $0.5 \mathrm{~mL}$ PCR tubes, and microwave-treated ( $750 \mathrm{~W}$ for $5 \mathrm{~min}$ ). Then $50 \mu \mathrm{L} \mathrm{ddH}_{2} 0$ was added to the individual tubes, and the thalli (or antennal parts) were manually crushed using a sterile pipette tip under a dissecting microscope. Some loss of material did occur by capillary action, but it was minimal. The PCR tubes were incubated at $-20^{\circ} \mathrm{C}$ for $10 \mathrm{~min}$. Strong pressure was applied to the ice inside the PCR tubes to further break apart thalli using a sterile pipette tip.

(4) ISOLATE II Plant DNA Kit: Up to twenty thalli were removed from the host and transferred to $1.5 \mathrm{~mL}$ Eppendorf tubes with 20-50 $\mu \mathrm{L} 95 \%$ ethanol. Alternatively, in the case of Herpomyces ectobiae on Blattella germanica, a piece of an antenna was isolated and transferred altogether. The 1.5 $\mathrm{mL}$ tubes were vacuum-dried at room temperature. Thalli were subsequently crushed in liquid nitrogen, using a sterile pipette with melted-closed tip. CTAB-based isolation buffer (PA1, ISOLATE II Plant DNA Kit) was added to the tubes and incubated in liquid nitrogen for $3 \mathrm{~min}$, followed by incubation in a heat block set at $65-90{ }^{\circ} \mathrm{C}$ for $3 \mathrm{~min}$. This cycle of freezing/ heating was repeated twice. Further steps were performed following the ISOLATE II Plant DNA Kit manufacturer's protocol.

\section{PCR amplification and DNA sequencing}

Three gene loci were amplified: partial rDNA SSU (ca 1100 bp), rDNA ITS (including ITS1, 5.8S and ITS2; ca 500 bp), and partial rDNA LSU (ca 1300 bp). PCR amplification was performed using both previously published and newly designed primers (Table 1). Laboulbeniales-specific primers were designed for the SSU region based on existing sequences in GenBank (Table 1). PCR reactions were performed according to the protocols listed in the respective reference for mentioned primers, or, in the case of the Extract-N-Amp Plant PCR Kit, according to the suggested protocol in the manufacturer's instructions. When PCR reactions did not produce clear bands during gel electrophoresis, conditions were optimized to include a two-step $\left(60{ }^{\circ} \mathrm{C}, 55^{\circ} \mathrm{C}\right)$ "touch-down" annealing phase (Sohrabi et al. 2010). In some cases, a semi-nested "touchdown" PCR was performed, using the product of the first, unsuccessful PCR reaction (e.g. PCR 1 using primers LROR and LR5, semi-nested PCR using the product of PCR 1 with primers LROR and LR3).

Products that showed clear bands on agarose gel were cleaned with Qiaquick PCR Purification Kit (Qiagen, Stanford, CA) or ExtractMe DNA Gel-out kit (Blirt, Gdańsk, Poland) and subsequently sequenced. We prepared $10 \mu \mathrm{L}$ sequencing reactions containing the same primer pairs and $1 \mu \mathrm{L}$ of purified PCR product. The sequencing reactions were performed using the Big Dye ${ }^{\circledR}$ Terminator v3.1 Cycle Sequencing Kit (Life Technologies, Carlsbad, CA).

Sequences were trimmed, edited and assembled in Sequencher 4.10.1 (Gene Codes Corporation, Ann Arbor, $\mathrm{MI})$. We performed BLAST searches on all of our sequences at http://ncbi.nlm.nih.gov/blast/Blast.cgi for similar sequences. For genera not yet represented in GenBank we compared sequences with our personal database, which is accessible at the Harvard University Herbaria internal server.

\section{RESULTS}

Our study shows that some simple, general DNA extraction protocols work. The commercial kits we tested are widely available.

Table 2 shows the success rates of the individual protocols, per genus extracted. Extractions using the QIAamp DNA Micro Kit yielded the lowest rates of success among the tested protocols, with seemingly no effect of pre-treatment. The overall success rate was $22 \%$ ( $n=27$ extractions total), for Hesperomyces virescens extractions the success rate was $35 \%(n=17)$. Overall success of the Extract-N-Amp Plant PCR Kit was $64 \%(n=66)$, with 92 $\%$ success for Herpomyces spp. (n = 13) and $66 \%$ for $H$. virescens $(n=35)$. For the third, heat-extraction protocol the success rate was $83 \%$ for Herpomyces ectobiae ( $n$ $=6$ ) and $100 \%$ for $H$. virescens $(n=3)$. The ISOLATE II Plant DNA Kit gave an overall success rate of $59 \%(n=$ $34)$, with a $100 \%$ success rate for $H$. ectobiae $(n=5)$ and $86 \%$ for $H$. virescens $(n=7)$. Interestingly, extracting DNA of Laboulbenia species was only successful $20 \%$ of the time with the Extract-N-Am Plant PCR Kit and $10 \%$ with the ISOLATE II Plant DNA Kit. Four extraction attempts of Laboulbenia species with the QIAamp DNA Micro Kit were unsuccessful.

We generated 43 sequences (SSU, ITS, and/ or LSU rDNA) for 18 isolates of the following species: Gloeandromyces nycteribiidarum, Herpomyces chaetophilus, $H$. ectobiae, $H$. periplanetae, $H$. stylopygae, Hesperomyces virescens, Laboulbenia diopsidis, Monoicomyces invisibilis, Polyandromyces coptosomalis, Rhachomyces philonthinus, Rickia wasmannii, and Zodiomyces vorticellarius (Table 3). Rhachomyces philonthinus was removed from a specimen 
Table 1. List of primers used for PCR amplification of small subunit (SSU), internal transcribed spacer (ITS), and large subunit (LSU) rDNA.

\begin{tabular}{|c|c|c|c|c|}
\hline Locus & Primer name & & Sequence & Reference \\
\hline SSU rDNA & NS1 & forward & GTAGTCATATGCTTGTCTC & White et al. 1990 \\
\hline SSU rDNA & NS2 & reverse & GGCTGCTGGCACCAGACTTGC & White et al. 1990 \\
\hline SSU rDNA & NS4 & reverse & CTTCCGTCAATTCCTTTAAG & White et al. 1990 \\
\hline SSU rDNA & SL344 & forward & GGTCGCAAGGCTGAAACTTA & Landvik et al. 1997 \\
\hline SSU rDNA & NS6 & reverse & GCATCACAGACCTGTTATTGCCTC & White et al. 1990 \\
\hline SSU rDNA & SL122 & forward & AGGCGCGCAAATTACCCAAT & Landvik et al. 1997 \\
\hline SSU rDNA & SR4 & reverse & AAACCAACAAAATAGAA & R. Vilgalys unpublished \\
\hline SSU rDNA & NSL1 & forward & GTAGTGTCCTCrCATGCTTTTGAC & present study \\
\hline SSU rDNA & NSL2 & reverse & AATCУAAGAATTTCACСTCTGAC & present study \\
\hline SSU rDNA & L & forward & AACCTGGTTGATCCTGCCAGT & Wrzosek 2000 \\
\hline SSU rDNA & 402 & forward & GCTACCACATCCAAGGAAGGCA & Wrzosek 2000 \\
\hline SSU rDNA & 416 & reverse & ATTTGCGCGCCTGCTGCCTTCC & Wrzosek 2000 \\
\hline SSU rDNA & 895 & forward & GTCAGAGGTGAAATTCTTGGAT & Wrzosek 2000 \\
\hline SSU rDNA & 898 & reverse & TAAATCCAAGAATTTCACСТCT & Wrzosek 2000 \\
\hline SSU rDNA & 1144 & forward & GCCTGCGGCTTAATTTGACTCAACA & Wrzosek 2000 \\
\hline SSU rDNA & 1308 & reverse & CTCGTTCGTTAACGGAATTAACC & Wrzosek 2000 \\
\hline SSU rDNA & $\mathrm{R}$ & reverse & TGATCCTTCTGCAGGTTCACCTACG & Wrzosek 2000 \\
\hline ITS rDNA & ITS1f & forward & CTTGGTCATTTAGAGGAAGTAA & Gardes \& Bruns 1993 \\
\hline ITS rDNA & ITS4 & reverse & TCCTCCGCTTATTGATATGC & White et al. 1990 \\
\hline ITS rDNA & ITS4_kyo1 & reverse & TCCTCCGCTTWTTGWTWTGC & Toju et al. 2012 \\
\hline ITS rDNA & ITS5 & forward & GGAAGTAAAAGTCGTAACAAGG & White et al. 1990 \\
\hline ITS rDNA & ITS2 & reverse & GCTGCGTTCTTCATCGATGC & White et al. 1990 \\
\hline LSU rDNA & LROR & forward & ACCCGCTGAACTTAAGC & R. Vilgalys unpublished \\
\hline LSU rDNA & LR1R & forward & AGGAAAAGAAACCAACC & Moncalvo et al. 1993 \\
\hline LSU rDNA & LIC24R & forward & GAAACCAACAGGGATTG & Miadlikowska \& Lutzoni 2000 \\
\hline LSU rDNA & LR3 & reverse & GGTCCGTGTTTCAAGAC & Vilgalys \& Hester 1990 \\
\hline LSU rDNA & LR5 & reverse & ATCCTGAGGGAAACTTC & Vilgalys \& Hester 1990 \\
\hline LSU rDNA & LR7 & reverse & TACTACCACCAAGATCT & Vilgalys \& Hester 1990 \\
\hline LSU rDNA & NL1 & forward & GCATATCAATAAGCGGAGGAAAAG & Kurtzman \& Robnett 1997 \\
\hline LSU rDNA & NL4 & reverse & GGTCCGTGTTTCAAGACGG & Kurtzman \& Robnett 1997 \\
\hline
\end{tabular}

of Philonthus that had been collected by Tomasz Majewski in August 2004. The host specimen was preserved for 11 years in $70 \%$ ethanol.

We were able to extract DNA from thalli of Hesperomyces virescens from dried insect specimens (with the Extract- $\mathrm{N}$ Amp Plant PCR Kit); on Cycloneda sanguinea sanguinea from Guatemala collected in May 2013, and on Harmonia axyridis from Massachusetts collected in August 2006 (details in Haelewaters et al. 2015b). Extractions were performed from H. paranensis on a dried Archimandrita tessellata (Blattodea: Blaberidae) collected in 2001 [deposited at the Harvard Museum of Comparative Zoology] and from Rodaucea sp. on a dried Cholevinae sp. (Coleoptera: Leiodidae) collected in 1991 [part of the collection of Invertebrate Zoology at the American Museum of Natural History], but no bands were noted on the agarose gel after PCR.

\section{DISCUSSION}

\section{Micromanipulation practices}

Laboulbeniales are more problematic to work with than many other groups of fungi. One of the main difficulties is their small size, which requires sterile micromanipulation with precise micropin handling.

It is preferable to separate thalli from the host's body, but minute thalli of Rickia, Herpomyces or Siemaszkoa are hard to detach. Using whole infected body parts in an extraction makes the procedure faster and easier. Most of the primers used in this study do not amplify the host insect's DNA, However, amplification of insect DNA by some primers may happen (as with LROR/LR7 and the sets of SSU primers used in Wrzosek 2000). Prominent appendages, such as those in many species of Laboulbenia or or Rhachomyces, pose another difficulty; debris is often observed to stick to the appendages and is very hard to impossible to wash away. In this case contamination with fungal propagules may be inevitable. Laboulbeniales-specific primers will serve to reduce the chance of amplifying non-target DNA. Another 
Table 2. Success rates per DNA extraction protocol used in this study, for all tested genera. Laboulbeniales from dried host insects were only extracted using the Extract-N-Amp Plant PCR Kit.

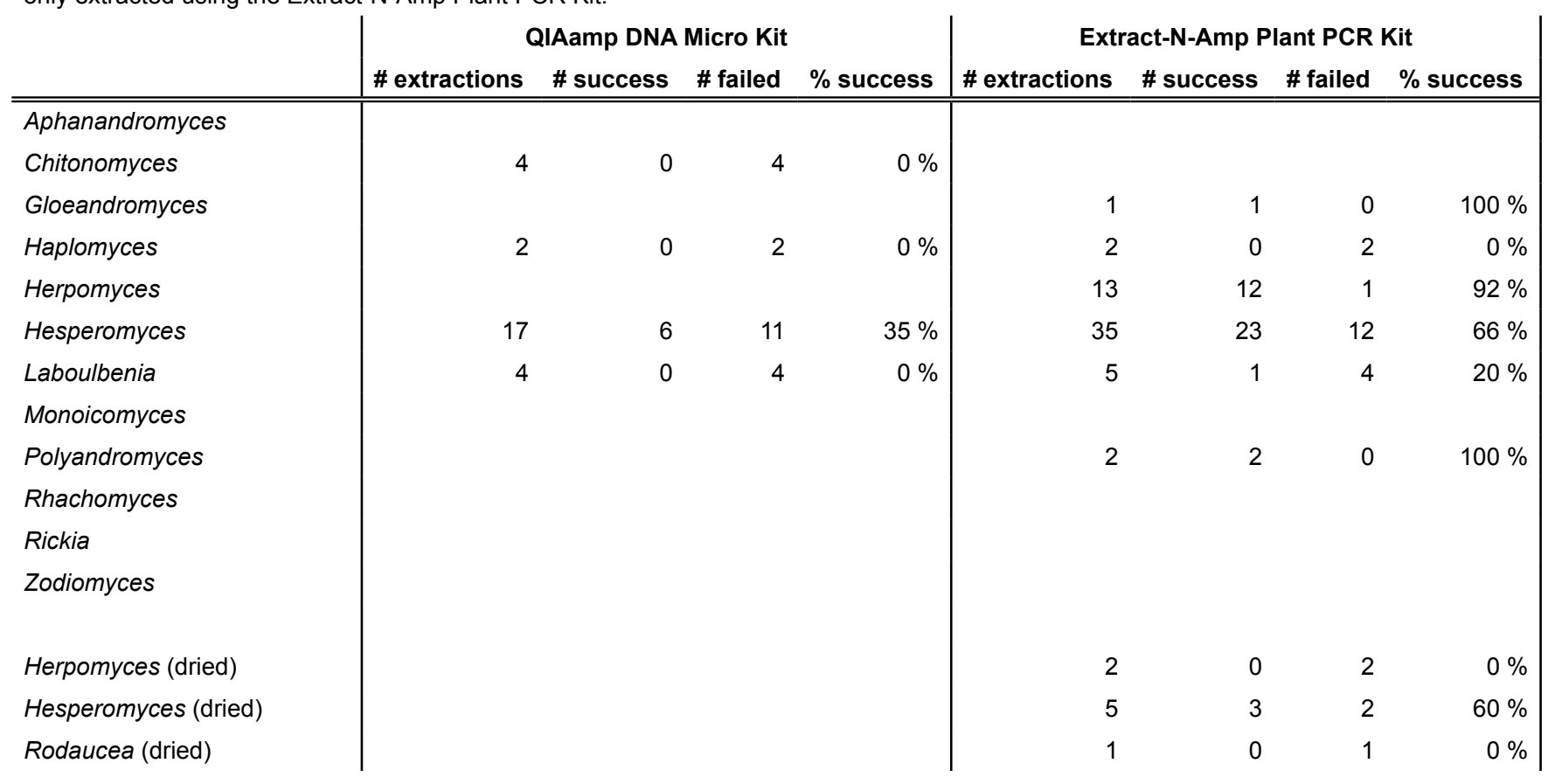

\begin{tabular}{|c|c|c|c|c|c|c|c|c|}
\hline & \multicolumn{4}{|c|}{ Heat-extraction protocol } & \multicolumn{4}{|c|}{ ISOLATE II Plant DNA Kit } \\
\hline & \# extractions & \# success & \# failed & $\%$ success & \# extractions & \# success & \# failed & $\%$ success \\
\hline Aphanandromyces & & & & & 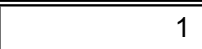 & 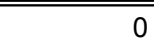 & 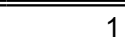 & $0 \%$ \\
\hline Chitonomyces & & & & & & & & \\
\hline Gloeandromyces & & & & & & & & \\
\hline Haplomyces & & & & & & & & \\
\hline Herpomyces & 6 & 5 & 1 & $83 \%$ & 5 & 5 & 0 & $100 \%$ \\
\hline Hesperomyces & 3 & 3 & 0 & $100 \%$ & 7 & 6 & 1 & $86 \%$ \\
\hline Laboulbenia & & & & & 10 & 1 & 9 & $10 \%$ \\
\hline Monoicomyces & & & & & 6 & 4 & 2 & $67 \%$ \\
\hline Polyandromyces & & & & & & & & \\
\hline Rhachomyces & & & & & 2 & 1 & 1 & $50 \%$ \\
\hline Rickia & 11 & 5 & 6 & $45 \%$ & & & & \\
\hline Zodiomyces & & & & & 3 & 3 & 0 & $100 \%$ \\
\hline
\end{tabular}

option is to simply excise the appendage system prior to extraction.

\section{Preservation techniques}

One of the most important concerns regarding successful molecular research is the method employed for preservation of material. The most effective option for extraction of Laboulbeniales DNA involves using freshly collected material preferably stored in $\geq 95 \%$ ethanol. These two factors certainly contribute to most of our DNA isolation positive results. Storage in $\geq 95 \%$ ethanol generally provides good DNA preservation for a prolonged period of time. Our DNA extraction protocols enabled us to amplify DNA and generate sequences from Laboulbeniales material that was on average 1-2 years old (one specimen was 11 years old), which is a novel development. Conditions that consistently yielded good results included: freshly collected specimens of larger species of Laboulbeniales, which provide ample DNA concentration even from a single thallus (e.g. Zodiomyces vorticellarius), and mature ascospore-containing thalli, which provide a higher concentration of DNA compared to immature or old thalli (always without ascospores). Many entomological practices involve preservation methods that interfere with successful DNA extraction of either the host or its associated fungi: most insect specimens are pinned in museum collections or preserved on $70 \%$ ethanol.

For morphological study of Laboulbeniales, researchers are able to make use of the many excellent systematic insect collections in natural history museums around the world. Such collections of dried pinned insects give relatively easily access to data (e.g. Weir \& Hammond 1997, Haelewaters et al. 2014). However, to date, extracting DNA from dried specimens has resulted in a $100 \%$ failure rate (Weir \& Blackwell 2001b). We present sequences obtained from two 
Table 3. Detailed collecting data, method of preservation, number of thalli used in extraction, DNA extraction protocol, and GenBank accession numbers for SSU, ITS, and LSU rDNA sequences of 18 isolates. NB: Table 3 is best viewed in a 2-page view, as it continues on the next page.

\begin{tabular}{|c|c|c|c|c|c|}
\hline Genus & Species & Isolate & Host & COUNTRY: locality & Collector \\
\hline Gloeandromyces & nycteribiidarum & $\mathrm{DH} 619 \mathrm{a}$ & Streblidae sp. & TRINIDAD & J.C. Camacho \\
\hline Herpomyces & chaetophilus & $\mathrm{DH} 602 \mathrm{~b}$ & Periplaneta americana & $\begin{array}{l}\text { USA: Massachusetts, } \\
\text { Cambridge, Kirkland House }\end{array}$ & T.W. Wang \\
\hline Herpomyces & ectobiae & MG001 & Blattella germanica & POLAND: Warsaw & M. Gorczak \\
\hline Herpomyces & periplanetae & $\mathrm{DH} 602 \mathrm{c}$ & Periplaneta americana & $\begin{array}{l}\text { USA: Massachusetts, } \\
\text { Cambridge, Kirkland House }\end{array}$ & T.W. Wang \\
\hline Herpomyces & stylopygae & DE_HerpBL1 & Blatta lateralis & HUNGARY & W.P. Pfliegler \\
\hline Hesperomyces & virescens & $\mathrm{DH} 167 \mathrm{e}$ & Cycloneda sanguinea sanguinea & $\begin{array}{l}\text { GUATEMALA: } \\
\text { Huehuetenango Dept., La } \\
\text { Laguna }\end{array}$ & R.S. Zack \\
\hline Hesperomyces & virescens & JP353a & Olla v-nigrum & $\begin{array}{l}\text { USA: Georgia, Peach } \\
\text { County, USDA-ARS }\end{array}$ & E. Brooks Thompson \\
\hline Hesperomyces & virescens & $\mathrm{DH} 486 \mathrm{c}$ & Harmonia axyridis & $\begin{array}{l}\text { USA: Massachusetts, } \\
\text { World's End peninsula }\end{array}$ & J. Rykken \\
\hline Hesperomyces & virescens & DH646c & Harmonia axyridis & $\begin{array}{l}\text { GERMANY: Bavaria state, } \\
\text { Bereuth }\end{array}$ & S. Tragust \\
\hline Hesperomyces & virescens & HM497c & Harmonia axyridis & $\begin{array}{l}\text { USA: Georgia, Peach } \\
\text { County, USDA-ARS }\end{array}$ & E. Brooks Thompson \\
\hline Hesperomyces & virescens & DE_HV01 & Harmonia axyridis & HUNGARY: Debrecen & W.P. Pfliegler \\
\hline Hesperomyces & virescens & MT001 & Harmonia axyridis & POLAND: Warsaw & M. Tischer \\
\hline Laboulbenia & diopsidis & $\mathrm{DH} 468 \mathrm{a}$ & Diopsidae sp. & $\begin{array}{l}\text { SIERRA LEONE: Eastern } \\
\text { Province, Nemahugoima }\end{array}$ & W. Rossi \\
\hline Monoicomyces & invisibilis & MT004 & Anotylus sculpturatus & POLAND: Warsaw & M. Tischer \\
\hline Polyandromyces & coptosomalis & $\mathrm{DH} 313 \mathrm{f}$ & Phoeacia sp. nov. & $\begin{array}{l}\text { ECUADOR: Orellana } \\
\text { Province, Quito }\end{array}$ & D. Forero \\
\hline Rhachomyces & philonthinus & TM10446 & Philonthus sp. & $\begin{array}{l}\text { POLAND: } \\
\text { Zachodniopomorskie, } \\
\text { Łobżany }\end{array}$ & T. Majewski \\
\hline Rickia & wasmannii & DE_Rak4 & Myrmica scabrinodis & HUNGARY: Rakaca & A. Tartally \\
\hline Zodiomyces & vorticellarius & MG003 & Helochares obscurus & POLAND: Warsaw & M. Gorczak \\
\hline
\end{tabular}

collections of $H$. virescens from dried ladybirds (DH167e and DH486c) collected in 2013 and 2006, respectively. Often thalli acquired from dried hosts are in poor condition and both identification based on morphological characters and DNA extraction may be a challenge.

Many insects in entomological collections are preserved in $70 \%$ ethanol. This decreases the DNA quality of the insect and its associates - especially after an extended period of storage (e.g. A'Hara et al. 1998). Some studies have generated short segments of mitochondrial DNA (<300 bp) from material in $70 \%$ ethanol (e.g. Colgan et al. 2002). For phylogenetic studies, however, longer segments are needed, and these need to be acquired from non-degraded DNA. Non-degraded DNA is also required for PCR amplification of low copy-number nuclear genes commonly used in modern fungal phylogenies (e.g. Hibbett et al. 2007, Hansen et al. 2013, Wang et al. 2014). If $70 \%$ ethanol was used to preserve insect hosts, it comes as no surprise that the DNA of Laboulbeniales harvested from them is adversely affected.

When working with Laboulbeniales from dried collections, another challenge is that information about the habitat or methods of collection and preservation is typically sparse. The extraction of DNA from insects can be drastically affected by using certain media (such as killing agents in pitfall traps) that degrade DNA. Some commonly used materials such as ethylene glycol or formalin have been linked to considerable DNA degradation (e.g. Dillon et al. 1996, Stoeckle et al. 2010).

\section{Negative results}

Our negative results can be explained based on protocols employed and/or the nature of the fungi that were under investigation. The $100 \%$ failure rate of the QIAamp DNA 


\begin{tabular}{|c|c|c|c|c|c|c|}
\hline $\begin{array}{l}\text { Year of } \\
\text { collection }\end{array}$ & Preservation & Number of thalli used & Extraction protocol & SSU & ITS & LSU \\
\hline 2014 & $95 \% \mathrm{EtOH}$ & 12 thalli & $\begin{array}{l}\text { Extract-N-Amp (with } \\
\text { glycerine) }\end{array}$ & & & "KT800008 \\
\hline 2014 & $95 \% \mathrm{EtOH}$ & 10 female thalli & $\begin{array}{l}\text { Extract-N-Amp (with } \\
\text { glycerine) }\end{array}$ & KT800023 & KT800039 & KT800009 \\
\hline 2014 & $95 \% \mathrm{EtOH}$ & $\begin{array}{l}\text { piece of antenna with } \pm 20 \text { adult } \\
\text { thalli }\end{array}$ & $\begin{array}{l}\text { ISOLATE II Plant DNA } \\
\text { Kit without freeze/thaw }\end{array}$ & KT800024 & KT800040 & \\
\hline 2014 & $95 \% \mathrm{EtOH}$ & 11 female thalli & $\begin{array}{l}\text { Extract-N-Amp (with } \\
\text { glycerine) }\end{array}$ & KT800025 & KT800041 & KT800010 \\
\hline 2014 & $80 \% \mathrm{EtOH}$ & $\begin{array}{l}\text { piece of antenna with } \pm 30 \text { adult } \\
\text { thalli }\end{array}$ & Heat-extraction & KT800026 & KT800042 & KT800011 \\
\hline 2013 & dried & 18 adult thalli & Extract-N-Amp & KT800027 & & KT800012 \\
\hline 2014 & $95 \% \mathrm{EtOH}$ & 10 adult thalli & QIAamp DNA Micro Kit & KT800028 & KT800043 & KT800013 \\
\hline 2006 & dried & 16 adult thalli & $\begin{array}{l}\text { Extract-N-Amp (with } \\
\text { glycerine) }\end{array}$ & KT800029 & KT800044 & KT800014 \\
\hline 2013 & $95 \% \mathrm{EtOH}$ & 2 adult thalli & Extract-N-Amp & & KT800045 & KT800015 \\
\hline 2014 & $95 \% \mathrm{EtOH}$ & 15 adult thalli & $\begin{array}{l}\text { Extract-N-Amp (with } \\
\text { Hoyer's medium) }\end{array}$ & KT800030 & KT800046 & KT800016 \\
\hline 2014 & $80 \% \mathrm{EtOH}$ & 9 adult thalli & Heat-extraction & KT800031 & KT800047 & KT800017 \\
\hline 2015 & $95 \% \mathrm{EtOH}$ & 1 adult thallus & $\begin{array}{l}\text { ISOLATE II Plant DNA } \\
\text { Kit }\end{array}$ & KT800032 & KT800048 & KT800018 \\
\hline 2013 & $100 \% \mathrm{EtOH}$ & 12 adult thalli & Extract-N-Amp & KT800033 & KT800049 & KT800019 \\
\hline 2015 & $95 \% \mathrm{EtOH}$ & 1 adult thallus & $\begin{array}{l}\text { ISOLATE II Plant DNA } \\
\text { Kit }\end{array}$ & KT800034 & & \\
\hline 2009 & $95 \% \mathrm{EtOH}$ & 7 female and 2 male thalli & Extract-N-Amp & KT800035 & & KT800020 \\
\hline 2004 & $70 \% \mathrm{EtOH}$ & \pm 15 adult thalli & $\begin{array}{l}\text { ISOLATE II Plant DNA } \\
\text { Kit }\end{array}$ & KT800036 & & \\
\hline 2014 & $80 \% \mathrm{EtOH}$ & 30 adult thalli & Heat-extraction & KT800037 & KT800050 & KT800021 \\
\hline 2015 & $95 \% \mathrm{EtOH}$ & 1 adult thallus & $\begin{array}{l}\text { ISOLATE II Plant DNA } \\
\text { Kit }\end{array}$ & KT800038 & & KT800022 \\
\hline
\end{tabular}

Micro Kit for Chitonomyces, Haplomyces, and Laboulbenia is largely due to the fact that no pre-treatments were carried out for these extracts. However, for one Laboulbenia extraction using this protocol a pre-treatment was done involving two cycles of heating to $95{ }^{\circ} \mathrm{C}$ and freezing on liquid nitrogen. Then why was this extraction unsuccessful? Laboulbenia species are generally heavily melanized, and the melanin pigment seems to hinder PCR amplification reactions (Eckhart et al. 2000). Also in the Extract-N-Amp Plant PCR Kit and the ISOLATE II Plant DNA Kit the success of extracting DNA and subsequent PCR amplification of Laboulbenia species is considerably lower compared to other genera. This observation shows that variables other than isolation techniques, such as the presence of pigments, are important to the success of DNA extraction and amplification. The 0 $\%$ success rate of Haplomyces using both the QIAamp DNA
Micro Kit and the Extract-N-Amp Plant PCR Kit probably is due to the combination of two factors: (1) the extract received no pre-treatment; and (2) host insects were collected and preserved (for four to five years) in $70 \%$ ethanol. The relatively low success rate with Rickia, with the heat-extraction protocol, may be explained by the fact that these small but very rigid thalli are difficult to break during the treatments that were applied; visual inspection after performing the entire protocol shows many intact thalli. Thus, the amount of DNA available for the Taq polymerase during PCR was limited, despite the high number of thalli (20-30) per reaction.

We can only hint at the low success rate of extractions from dried material. The extraction of Rodaucea sp. received no pre-treatment and the thalli were removed from a cholevine specimen collected in 1991. It might have been too old for successful DNA extraction. The same may be true 
for the unsuccessful attempts to extract DNA of Herpomyces paranensis from a pinned specimen of Archimandrita tessallata from 2001.

\section{CONCLUSIONS}

Even with fresh thalli available, successful extraction of DNA has been one of the greatest obstacles in applying molecular methods to research on Laboulbeniales. Their minute size, the difficulty in fracturing thalli to release DNA, and the fact that (to date) they remain resistant to isolation into culture makes molecular protocols applied to Laboulbeniales difficult. This is the reason "laboulbeniologists" need: (1) colleagues (entomologists) or museums to provide high-quality, properly prepared samples; and (2) DNA isolation protocols that focus heavily on deep homogenization of the material. Microwave heating, submersion in liquid nitrogen, freeze/thaw cycles, and simple yet effective crushing with pipette tips are all means of destroying the tough cell walls without damaging the DNA.

As stated in previous studies, both the SSU and ITS portions of rDNA are suited for molecular phylogenetics of the Laboulbeniales and universal fungal primers for these regions work well for most of the species (Weir \& Blackwell 2001b, Goldmann \& Weir 2012, Weir \& Hughes 2002, Goldmann et al. 2013)). We have found that LSU sequences are also easily to obtain. Designing specific primers often facilitates the work. Well-designed primers specific for Laboulbeniales may perform better and their specificity helps to avoid contamination. As the number of genes being used in fungal phylogenetic studies increases it will be important that these new genes/regions/markers be explored in the Laboulbeniales as well.

We hope that sharing our experience with various techniques for extraction and PCR amplification of Laboulbeniales DNA will have a positive effect on present and future molecular biology research of Laboulbeniomycetes - the only class among the Ascomycota without a reliable multi-gene phylogeny.

\section{ACKNOWLEDGEMENTS}

DH acknowledges funding from the Harvard University Graduate School of Arts and Sciences, the American Museum of Natural History (Theodore Roosevelt Memorial Grant), and the National Park Service. AT was supported by the 'AntLab' Marie Curie Career Integration Grant within the 7th European Community Framework Programme and by a 'Bolyai János' scholarship of the Hungarian Academy of Sciences (MTA). This manuscript would not have come together without the various contributions of the many researchers, collaborators, and friends. For collecting and/or identifying host specimens used in this study: Elizabeth Brooks Thompson, Jasmin C. Camacho, Ted E. Cottrell, André De Kesel, Dimitri Forero, Thereza de A. Garbelotto, Louis S. Hesler, Heidi Hopkins, Walter Rossi, Jessica J. Rykken, Simon Tragust, Piotr Tykarski, Tristan W. Wang, and Richard S. Zack. For advice and helpful discussions: Rosanne A. Healy, Katherine F. LoBuglio, and Feng Xu. For assisting in the molecular lab: Harvard College undergraduates Hamidah Mahmud, Julie Park, and Tristan W. Wang. For general support: André De
Kesel, István Pócsi, Matthias Sipiczki, and Tomasz Majewski. For reviewing earlier drafts of the manuscript: Pedro W. Crous, André De Kesel, David L. Hawksworth, Rosanne A. Healy, Monica Hughes, Tomasz Majewski, and Walter Rossi. DH would like to specifically thank Lee H. Herman at the American Museum of Natural History and Brian D. Farrell and Philip Perkins at the Harvard Museum of Comparative Zoology for curatorial support.

\section{REFERENCES}

A'Hara S, Harling R, McKinlay RG, Topping CJ (1998) RAPD profiling of spider (Araneae) DNA. Journal of Arachnology 26: 397-400.

Colgan DJ, Brown S, Major RE, Christie F, Gray MR, Cassis G (2002) Population genetics of wolf spiders of fragmented habitat in the wheat belt of New South Wales. Molecular Ecology 11: 2295-2305.

Conger AD, Fairchild LM (1953) A quick-freeze method for making smear slides permanent. Stain Technology 28: 281-283.

De Kesel A (1996a) Relative importance of direct and indirect infection in the transmission of Laboulbenia slackensis (Ascomycetes, Laboulbeniales). Belgian Journal of Botany 128: 124-130.

De Kesel A (1996b) Host specificity and habitat preference of Laboulbenia slackensis. Mycologia 88: 565-573.

De Kesel A (1998) Identification and host-range of the genus Laboulbenia in Belgium. Sterbeeckia 18: 13-31.

De Kesel A (2011) Hesperomyces (Laboulbeniales) and coccinellid hosts. Sterbeeckia 30: 32-37.

De Kesel A, Haelewaters D (2012) Belgian records of Laboulbeniales from aquatic insects (2) - Chitonomyces aculeifer. Sterbeeckia 31: 16-18.

De Kesel A, Haelewaters D (2014) Laboulbenia slackensis and L. littoralis sp. nov. (Ascomycota, Laboulbeniales), two sibling species as a result of ecological speciation. Mycologia 106: 407-414.

Dillon N, Austin AD, Bartowsky E (1996) Comparison of preservation techniques for DNA extraction from hymenopterous insects. Insect Molecular Biology 5: 21-24.

Eckhart L, Bach J, Ban J, Tschachler E (2000) Melanin binds reversibly to thermostable DNA polymerase and inhibits its activity. Biochemical and Biophysical Research Communications 271: 726-730.

Ferreira AVB, Glass NL (1996) PCR from fungal spores after microwave treatment. Fungal Genetics Newsletter 43: 25-26.

Gardes M, Bruns TD (1993) ITS Primers with enhanced specificity for Basidiomycetes - application to the identification of mycorrhizae and rusts. Molecular Ecology 2: 113-118.

Giard A (1892) Sur une Laboulbéniacée (Thaxteria künckeli nov. gen. et sp.), parasite de Mormolyce phyllodes Hagenbach. Comptes Rendus Hebdomadaires des Séances et Mémoires de la Société de Biologie 4: 156-158.

Goldmann L, Weir A (2012) Position specificity in Chitonomyces (Ascomycota, Laboulbeniomycetes) on Laccophilus (Coleoptera, Dytiscidae): a molecular approach resolves a century-old debate. Mycologia 104: 1143-1158.

Goldmann L, Weir A, Rossi W (2013) Molecular analysis reveals two new dimorphic species of Hesperomyces (Ascomycota, Laboulbeniomycetes) parasitic on the ladybird Coleomegilla maculata (Coleoptera, Coccinellidae). Fungal Biology 117: 807813. 
Goodwin DC, Lee SB (1993) Microwave miniprep of total genomic DNA from fungi, plants, protists and animals for PCR. BioTechniques 15: 438-441.

Haelewaters D (2011) Laboulbeniales: Exploring and testing DNA extraction protocols, carrion beetle hosts and species in 'De Kaaistoep' (Netherlands). Master thesis, Department of Biology, Ghent University, Belgium.

Haelewaters D, Comont RF, Zhao SY, Pfister DH (2014) Hesperomyces virescens (Fungi, Ascomycota, Laboulbeniales) attacking Harmonia axyridis (Coleoptera, Coccinellidae) in its native range. Chinese Science Bulletin 59: 528-532.

Haelewaters D, De Kock G, van Wielink P (2015a) Nieuwe Laboulbeniales in De Kaaistoep. In: Natuurstudie in De Kaaistoep. Verslag 2014, 20e onderzoeksjaar (Peeters T, van Eck A, Cramer T, eds): 11-18. Tilburg, The Netherlands: TWM Gronden.

Haelewaters D, Yaakop S (2014) New and interesting Laboulbeniales from southern and southeastern Asia. Mycotaxon 129: 439-454.

Haelewaters D, Zhao SY, De Kesel A, Royer IR, Handlin RE, Farrell BD, Pfister DH (2015b) Laboulbeniales (Ascomycota) of the Boston Harbor Islands I: species parasitizing Coccinellidae and Staphylinidae. Northeastern Naturalist 22: 459-477.

Hansen K, Perry BA, Dranginis AW, Pfister DH (2013) A phylogeny of the highly diverse cup-fungus family Pyronemataceae (Pezizomycetes, Ascomycota) clarifies relationships and evolution of selected life history traits. Molecular Phylogenetics and Evolution 67: 311-335.

Haugland RA, Heckman JL, Wymer LJ (1999) Evaluation of different methods for the extraction of DNA from fungal conidia by quantitative competitive PCR analysis. Journal of Microbiological Methods 37: 165-176.

Henson JM (1992) DNA hybridization and polymerase chain reaction (PCR) tests for identification of Gaeumannomyces, Phialophora and Magnaporthe isolates. Mycological Research 96: 629-636.

Hibbett DS, Binder M, Bischoff JF, Blackwell M, Cannon PF, et al. (2007) A higher-level phylogenetic classification of the Fungi. Mycological Research 3: 509-547.

Huldén L (1983) Laboulbeniales (Ascomycetes) of Finland and adjacent parts of the U.S.S.R. Karstenia 23: 31-136.

Kurtzman CP, Robnett CJ (1997) Identification of clinically important ascomycetous yeasts based on nucleotide divergence in the 5 , end of the large-subunit (26S) ribosomal DNA gene. Journal of Clinical Microbiology 35: 1216-1223.

Landvik S, Egger KN, Schumacher T (1997) Towards a subordinal classification of the Pezizales. Nordic Journal of Botany 17: 403-418.

Lee SB, Taylor JM (1990) Isolation of total DNA from fungi for amplification by the polymerase chain reaction. In: $P C R$ Protocols: a guide to methods and applications (Innis MA, Gelfand DH, Sninsky JJ, White TJ, eds): 282-287. San Diego: Academic Press.

Majewski T (1994) The Laboulbeniales of Poland. Polish Botanical Studies 7: 1-466.

Miadlikowska J, Lutzoni F (2000) Phylogenetic revision of the genus Peltigera (lichen-forming Ascomycota) based on morphological, chemical, and large subunit nuclear ribosomal DNA data. International Journal of Plant Sciences 161: 925-958.

Moncalvo J-M, Rehner SA, Vilgalys R (1993) Systematics of Lyophyllum section Difformia based on evidence from culture studies and ribosomal DNA sequences. Mycologia 85: 788-794.
Prieto M, Wedin M (2013) Dating the diversification of the major lineages of Ascomycota (Fungi). PLoS One 8: e65576.

Santamaría S (1998) Laboulbeniales, I. Laboulbenia. Flora Mycologica Iberica 4: 1-186.

Santamaría S (2003) Laboulbeniales, II. Acompsomyces-llyomyces. Flora Mycologica Iberica 5: 1-344.

Santamaría S, Espadaler X (2015) Rickia lenoirii, a new ectoparasitic species, with comments on world Laboulbeniales associated with ants. Mycoscience 56: 224-229.

Scheloske H-W (1969) Beiträge zur Biologie, Ökologie und Systematik der Laboulbeniales (Ascomycetes) unter besondere Berücksichtigung des Parasit-Wirt-Verhältnisses. Parasitologische Schriftenreihe 19: 1-176.

Schoch CL, Sung GH, López-Giráldez F, Townsend JP, Miadlikowska $\mathrm{J}$, et al. (2009) The Ascomycota tree of life: a phylum-wide phylogeny clarifies the origin and evolution of fundamental reproductive and ecological traits. Systematic Biology 58: 224239.

Sohrabi M, Myllys L, Stenroos S (2010) Successful DNA sequencing of a 75 year-old herbarium specimen of Aspicilia aschabadensis ( J. Steiner) Mereschk. Lichenologist 42: 626-628.

Spatafora JW, Sung GH, Johnson D, Hesse C, O'Rourke B, et al. (2006) A five-gene phylogeny of Pezizomycotina. Mycologia 98 1018-1028.

Stoeckle BC, Dworschak K, Gossner MM, Kuehn R (2010) Influence of arthropod sampling solutions on insect genotyping reliability. Entomologia Experimentalis et Applicata 135: 217-223.

Sugiyama K, Phanichapol D (1984) Laboulbeniomycetes (Ascomycotina) in Thailand, I. Natural History Bulletin of the Siam Society 31: 47-88.

Thaxter R (1896) Contribution towards a monograph of the Laboulbeniaceae. Memoirs of the American Academy of Arts and Sciences 12: 187-429.

Thaxter R (1899) Diagnosis of new species of Laboulbeniaceae. I. Proceedings of the American Academy of Arts and Sciences 35 153-209.

Thaxter R (1900) Preliminary diagnosis of new species of Laboulbeniaceae. II. Proceedings of the American Academy of Arts and Sciences 35: 409-450.

Thaxter R (1901a) Preliminary diagnosis of new species of Laboulbeniaceae. III. Proceedings of the American Academy of Arts and Sciences 36: 397-414.

Thaxter R (1901b) Preliminary diagnosis of new species of Laboulbeniaceae. IV. Proceedings of the American Academy of Arts and Sciences 37: 21-45.

Thaxter R (1902) Preliminary diagnosis of new species of Laboulbeniaceae. V. Proceedings of the American Academy of Arts and Sciences 38: 9-57.

Thaxter R (1905) Preliminary diagnoses of new species of Laboulbeniaceae. VI. Proceedings of the American Academy of Arts and Sciences 41: 303-318.

Thaxter R (1926) Contribution towards a monograph of the Laboulbeniaceae. Part IV. Memoirs of the American Academy of Arts and Sciences 15: 427-580.

Thiers B (2015) Index Herbariorum: a global directory of public herbaria and associated staff. New York Botanical Garden's Virtual Herbarium. http://sweetgum.nybg.org/science/ih/.

Toju H, Tanabe AS, Yamamoto S, Sato H (2012) High-coverage ITS primers for the DNA-based identification of ascomycetes and basidiomycetes in environmental samples. PLoS One 7: e40863. 
Vilgalys R, Hester M (1990) Rapid genetic identification and mapping of enzymatically amplified ribosomal DNA from several Cryptococcus species. Journal of Bacteriology 172: 4238-4246.

Wang Y, Tretter ED, Johnson EM, Kandel P, Lichtwardt RW, Novak SJ, Smith JF, White MM (2014) Using a five-gene phylogeny to test morphology-based hypotheses of Smittium and allies, endosymbiotic gut fungi (Harpellales) associated with arthropods. Molecular Phylogenetics and Evolution 79: 23-41.

Weir A, Beakes GW (1996) Correlative light- and scanning electron microscope studies on the developmental morphology of Hesperomyces virescens. Mycologia 88: 677-693.

WeirA, Blackwell M (2001a) Molecular data support the Laboulbeniales as a separate class of Ascomycota, Laboulbeniomycetes. Mycological Research 105: 1182-1190.

Weir A, Blackwell M (2001b) Extraction and PCR amplification of DNA from minute ectoparasitic fungi. Mycologia 93: 802-806.

Weir A, Hammond PM (1997) Laboulbeniales on beetles: host utilization patterns and species richness of the parasites. Biodiversity and Conservation 6: 701-719.
Weir A, Hughes M (2002) The taxonomic status of Corethromyces bicolor from New Zealand, as inferred from morphological, developmental, and molecular studies. Mycologia 94: 483-493.

Whisler HC (1968) Experimental studies with a new species of Stigmatomyces (Laboulbeniales). Mycologia 60: 65-75.

White TJ, Bruns TD, Lee SB, Taylor JW (1990) Analysis of phylogenetic relationships by amplification and direct sequencing of ribosomal RNA genes. In: PCR Protocols: a guide to methods and applications (Innis MA, Gelfand DH, Sninsky JJ, White TJ, eds): 315-322. San Diego: Academic Press.

Wrzosek M (2000) Taksonomia i filogeneza Mucorales (Zygomycetes) w świetle analiz morfometrycznych oraz wybranych markerów molekularnych. [Taxonomy and phylogeny of Mucorales (Zygomycetes) in the light of morphometrical and selected molecular markers analyses]. PhD thesis, University of Warsaw. 